\title{
EDITORIAL
}

\section{Cambios recientes a la lista de los mamíferos de Colombia}

\author{
Héctor E. Ramírez-Chaves \\ School of Biological Sciences, University of Queensland, Goddard Building 8, St. Lucia 4072, Brisbane, Australia. \\ hera.chaves@gmail.com
}

Andrés Felipe Suárez-Castro

School of Geography, Planning and Environmental Management, University of Queensland, Steele Building 3, St. Lucia 4072, Brisbane, Australia.

José F. González-Maya

Proyecto de Conservación de Aguas y Tierras, ProCAT Colombia-Internacional, Carrera 13 \# 96-82, Of. 202, Bogotá, Colombia \& Instituto de Ecología, Universidad Nacional Autónoma de México, México.

Debido al avance en el desarrollo de investigaciones de diversa índole que involucran mamíferos, cada año se reportan cambios en la riqueza de especies registradas en el territorio nacional. Un esfuerzo notable encaminado a actualizar el conocimiento de este grupo en el país señaló la presencia de 492 especies para el año 2013 (Solari et al. 2013). Este número se incrementó a 500 especies para el año 2014, a partir de revisiones sistemáticas o adiciones de nuevas localidades de distribución para varias especies neotropicales (Ramírez-Chaves \& Suárez-Castro 2014) y en esta revisión se aumenta el número de especies a 518 para el país. El incremento ha sido mayor para murciélagos (orden Chiroptera), grupo que actualmente cuenta con el número más alto de especies de mamíferos registradas en Colombia (205 especies). Sin embargo, el uso de nuevas técnicas y exploraciones de campo realizadas por diferentes investigadores han generado una gran cantidad de conocimiento para otros grupos, por lo que es necesario sintetizar la información de manera constante para que esté disponible a todos aquellos involucrados en estudiar y conservar la biodiversidad del país. Con el fin de actualizar el número de especies de mamíferos registradas en el territorio nacional, presentamos una valoración y actualización con los cambios recientes para Colombia durante los últimos meses (Tabla 1).

Cambios recientes en el número de especies de mamíferos registradas en Colombia

Roedores: El segundo volumen de la serie "Mammals of South America", dedicado al orden Rodentia (Patton et al. 2015), así como otras publicaciones recientes (Rodríguez-Posada 2014, Hanson et al. 2015) introdujeron cambios notables en el conocimiento de diversas especies de roedores presentes en Colombia. En total, 16 especies ingresan a la lista del país (Tabla 1), ya sea por extensiones geográficas (nueve especies), descripción de nuevas especies (una especie), o cambios taxonómicos (seis especies). La especie Microsciurus alfari fue restringida a Centroamérica por lo que se excluye de la fauna Sudamericana y en su lugar se reconocen tres especies adicionales en Colombia (de Vivo \& Carmignotto 2015). Además, los epítetos específicos de tres especies sufrieron cambios sin que estos afecten el conteo de especies nacional (Tabla 1). Por otra parte, tres especies fueron excluidas (Orthogeomys thaeleri, Proechimys magdalenae y Zygodontomys cherriei) por considerarse sinónimos recientes (Haffner 2015, Patton \& Leite 2015, Voss 2015). Estos cambios hacen que la riqueza de roedores para el país se incremente de 120 en 2014 (Ramírez-Chaves \& Suárez-Castro 2014) a 132 especies a la fecha.

Primates: Otro grupo que sufrió cambios importantes es Primates, para el cuál se adicionan siete especies (Tabla 1), dos de ellas del recientemente descrito género Cheracebus (C. lucifer, C. medemi; van Roosmalen et al. 2002, Rylands et al. 2012, Byrne et al. 2016), tres de Cebus (C. leucocephalus, C. malitosus, C. versicolor; Boubli et al. 2012, Rylands et al. 2013) y una de Saimiri (S. macrodon; Lynch Alfaro et al. 2015), las cuales fueron previamente consideradas como subespecies. A

\footnotetext{
Mammalogy Notes | Notas Mastozoológicas

Sociedad Colombiana de Mastozoología

Vol. 3 Num. 1| 2016
} 
nivel específico, Saimiri sciureus fue restringida a la región Amazónica de Brasil y Guayana por lo que las especies presentes en

Colombia son S. cassiquiarensis y S. macrodon (Lynch Alfaro et al. 2015). El número total de especies que se adicionan puede sin embargo variar si se siguen estrictamente las recomendaciones de Mittermeier et al. (2013), quienes mencionaron que el total de especies de primates en Colombia es de 45, aunque ciertos grupos como los géneros Cebus y Sapajus (e.g. el reconocimiento de Cebus cesarae y Sapajus macrocephalus como especies válidas para Colombia) requieren de mayor investigación. El incremento de especies para este grupo se debe mayormente a la aplicación del concepto filogenético de especie que se ha seguido en tratamientos recientes (ver Rylands et al. 2012, Mittermeier et al. 2013).

Chiroptera: Basados en la revisión de un espécimen depositado en el Museo de Historia Natural de Los Angeles (LACM), Moratelli \& Wilson (2014) registraron a la especie Myotis diminutus por primera vez en Colombia para la región del Chocó, en el departamento de Nariño. Esta corresponde a una extensión de distribución y se encuentra a $135 \mathrm{~km}$ al norte de la localidad tipo en Ecuador.

Soricomorpha: Cryptotis perijensis fue descrita recientemente por Quiroga-Cardona \& Woodman (2015) para la vertiente oriental de la Serranía de Perijá en Colombia y Venezuela.

Exclusiones y registros por confirmar: Dos especies de grandes mamíferos, el tapir Tapirus kabomani, y el venado Mazama bricenii son consideradas como sinónimos recientes de T. terrestris y M. rufina (Gutiérrez et al. 2015, Ruíz-García et al. 2015, 2016) a partir de datos genéticos, por lo tanto, son excluidas del conteo nacional. Además, dos especies de mamíferos medianos (Coendou bicolor y C. melanurus) fueron excluidas de la lista nacional por carecer de evidencia tangible de su presencia (Ramírez-Chaves et al. 2016). A nivel genérico, el nombre Callicebus quedó restringido para especies presentes en el oriente de Brasil (Byrne et al. 2016). Además, aunque A. nancymaae ya ha sido registrada en el Trapecio Amazónico, la distribución de poblaciones nativas establecidas en Colombia debe ser confirmada, puesto que en la actualidad existe un problema por introducción de individuos provenientes de Perú (Maldonado \& Peck 2014).

Cambios taxonómicos a nivel de género: A nivel genérico (Tabla 2), hubo en total cinco cambios, tres para roedores (Notosciurus, Guerlinguetus y Hadrosciurus) considerados previamente subgéneros de Sciurus en la región neotropical (de Vivo \& Carmignotto 2015), tres adiciones para murciélagos (Gardnerycteris para incluir a Mimon crenulatum; Hurtado \& Pacheco 2014; Aeorestes y Dasypterus para incluir a Lasiurus cinereus y Lasiurus ega, respectivamente; Baird et al. 2015), y tres de primates (Leontocebus para incluir a Saguinus nigricollis y Saguinus fuscus; Buckner et al. 2015; Cheracebus para incluir en Colombia a Callicebus lucifer, C. lugens, C. medemi y C. torquatus, y Plecturocebus para incluir a Callicebus caquetensis. C. discolor y C. ornatus; Byrne et al. 2016).

Todos estos cambios hacen que la lista de mamíferos de Colombia se incremente en 18 especies y ocho géneros, para un total de 518 especies (y 215 géneros), de las cuales 56 son endémicas (Tabla 2, S1). Posibles cambios taxonómicos adicionales, aunque todavía por definir y que pueden afectar el conteo de especies presentes en Colombia se han sugerido principalmente para marsupiales (Díaz-Nieto et al. 2016), roedores (D’Elia et al. 2015, Hanson et al. 2015), o murciélagos (Baird et al. 2015 para el antiguo género Lasiurus. Además, Velazco \& Patterson 2013 restringen Sturnira lilium para el Escudo Brasilero, aunque no se clarifica cuál es el taxón correspondiente en Colombia). Durante los últimos 30 años, el número de especies de mamíferos en Colombia se ha incrementado en 152, mientras que el número de especies endémicas se ha casi triplicado (Figura 1). El número de especies registradas (518) sitúa a Colombia como el sexto a nivel global en riqueza de especies (Tabla 3) y el cuarto en el continente americano después de Brasil con más de 700 especies, México con 538 especies para el año 2014, y Perú donde el número de especies supera fácilmente las 525. Esto se puede inferir a partir de adiciones a la valoración de mamíferos más reciente para Perú (Pacheco et al. 2009), las cuales incluyen especies de murciélagos (Lim et al. 2010, Díaz 2011, Calderón \& Pacheco 2012, Velazco \& Cadenillas 2011, Medina et al. 2014, Velazco et al. 2010, 2011, 2014), marsupiales (Solari et al. 2012), roedores (Jiménez et al. 2013, Pacheco et al. 2014, de Oliveira \& Gonçalves 2015, de

\footnotetext{
Mammalogy Notes | Notas Mastozoológicas

Sociedad Colombiana de Mastozoología

Vol. 3 Num. 1| 2016
} 
Editorial | Editorial

Vivo \& Carmignotto 2015, Hurtado \& Pacheco 2015, Rengifo \& Pacheco 2015, Spotorno \& Patton 2015, Tribe 2015) y primates (Marsh 2014, Vermeer \& Tello-Alvarado 2015).

Tabla 1. Cambios posteriores a la lista de mamíferos de Colombia con respecto a los trabajos de Solari et al. (2013) y Ramírez-Chaves \& Suárez-Castro (2014). Los departamentos siguen las abreviaturas sugeridas en Solari et al. (2013). EG: extensión geográfica; CT: cambios taxonómicos, NE: Descripción de nuevas especies.

\begin{tabular}{|c|c|c|c|c|}
\hline Taxón & Departamento & Altitud (msnm) & Referencias & Comentarios \\
\hline \multicolumn{5}{|l|}{ Soricomorpha, Soricidae } \\
\hline $\begin{array}{l}\text { Cryptotis perijensis Quiroga Carmona \& } \\
\text { Woodman, } 2015\end{array}$ & Ces & 2000 & $\begin{array}{l}\text { Quiroga-Carmona \& } \\
\text { Woodman } 2015\end{array}$ & NE \\
\hline \multicolumn{5}{|l|}{ Chiroptera, Vespertilionidae } \\
\hline Aeorestes sp. & $\begin{array}{l}\text { Boy Cau Cun } \\
\text { Mag San Tol } \\
\text { VdC }\end{array}$ & $250-3500$ & $\begin{array}{l}\text { Baird et al. 2015; Morales- } \\
\text { Martínez \& Ramírez-Chaves } \\
2015\end{array}$ & $1 \mathrm{CT}$ \\
\hline $\begin{array}{l}\text { Myotis diminutus Moratelli \& Wilson, } \\
2011\end{array}$ & Nar & 135 & Moratelli \& Wilson 2014 & EG \\
\hline \multicolumn{5}{|l|}{ Primates, Aotidae } \\
\hline \multicolumn{5}{|l|}{ Primates, Cebidae } \\
\hline Cebus leucocephalus Gray, 1865 & San & & Boubli et al. 2012 & $\mathrm{CT}$ \\
\hline Cebus malitosus Elliot, 1909 & LaG Mag & $0-500$ & Boubli et al. 2012 & $\mathrm{CT}$ \\
\hline Cebus versicolor Pucheran, 1845 & $\begin{array}{l}\text { Ant Bol Boy } \\
\text { Ces Cun NdS } \\
\text { Suc Tol }\end{array}$ & $20-2000$ & Boubli et al. 2012 & $\mathrm{CT}$ \\
\hline Saimiri cassiquiarensis Lesson, 1840 & Gua Met & $90-150$ & Lynch Alfaro et al. 2015 & $2 \mathrm{CT}$ \\
\hline Saimiri macrodon Elliot, 1907 & Ama Caq & & Lynch Alfaro et al. 2015 & CT \\
\hline \multicolumn{5}{|l|}{ Primates, Pitheciidae } \\
\hline Callicebus lucifer Thomas, 1914 & Ama & $90-200$ & $\begin{array}{l}\text { Rylands \& Russell A. } \\
\text { Mittermeier } 2013\end{array}$ & $\mathrm{CT}$ \\
\hline Callicebus medemi Hershkovitz, 1963 & Ama Caq Put & $0-500$ & $\begin{array}{l}\text { Rylands \& Russell A. } \\
\text { Mittermeier } 2013\end{array}$ & $\mathrm{CT}$ \\
\hline \multicolumn{5}{|l|}{ Rodentia, Sciuridae } \\
\hline Guerlinguetus aestuans (Linnaeus, 1766) & Vau & 100 & de Vivo \& Carmignotto 2015 & EG \\
\hline $\begin{array}{l}\text { Microsciurus isthmius (E. W. Nelson, } \\
\text { 1899) }\end{array}$ & $\begin{array}{l}\text { Ant Cau Cho } \\
\text { Nar VdC }\end{array}$ & $0-300$ & de Vivo \& Carmignotto 2015 & $\mathrm{CT}$ \\
\hline Microsciurus otinus (Thomas, 1901) & Ant Bol Cor & $200-1500$ & de Vivo \& Carmignotto 2015 & $\mathrm{CT}$ \\
\hline $\begin{array}{l}\text { Microsciurus similis (E. W. Nelson, } \\
\text { 1899) }\end{array}$ & $\begin{array}{l}\text { Ant Cau Cho } \\
\text { Nar VdC }\end{array}$ & $130-2200$ & de Vivo \& Carmignotto 2015 & $\mathrm{CT}$ \\
\hline \multicolumn{5}{|l|}{ Rodentia, Cricetidae } \\
\hline Necromys punctulatus (Thomas, 1894) & Cun & 2600 & Pardiñas et al. 2015 & EG \\
\hline $\begin{array}{l}\text { Neusticomys mussoi Ochoa \& Soriano, } \\
1991,\end{array}$ & San & 1504 & Rodríguez-Posada 2014 & EG \\
\hline $\begin{array}{l}\text { Neusticomys vossi Hanson, D’Elía, } \\
\text { Ayers, Cox, Burneo \& Lee Jr., } 2015\end{array}$ & Hui & 2200 & Hanson et al. 2015 & $\mathrm{NE}$ \\
\hline
\end{tabular}

Mammalogy Notes | Notas Mastozoológicas

Sociedad Colombiana de Mastozoología

Vol. 3 Num. 1| 2016 
Tabla 1. Continuación.

\begin{tabular}{|c|c|c|c|c|}
\hline Taxón & Departamento & Altitud (msnm) & Referencias & Comentarios \\
\hline Nectomys grandis Thomas, 1897 & $\begin{array}{l}\text { Ant Boy Cun } \\
\text { Hui NdS }\end{array}$ & $0-500$ & Bonvicino \& Weksler 2015 & 3 \\
\hline Nephelomys meridensis (Thomas, 1894) & Boy NdS & $1100-2440$ & Percequillo 2015 & 4 \\
\hline Oecomys roberti (Thomas, 1904) & $\mathrm{Caq}$ & 300 & Carleton \& Musser 2015 & EG \\
\hline $\begin{array}{l}\text { Oligoryzomys delicatus (J. A. Allen \& } \\
\text { Chapman, 1897) }\end{array}$ & $\begin{array}{l}\text { Ant Boy Cau } \\
\text { Ces Cun Met } \\
\text { Vau VdC Vic }\end{array}$ & $0-3300$ & Weksler \& Bonvicino 2015 & 5 \\
\hline $\begin{array}{l}\text { Rhipidomys leucodactylus (Tschudi, } \\
\text { 1845) }\end{array}$ & Caq Met & $200-1000$ & Tribe 2015 & EG \\
\hline Rhipidomys sp. nov & Mag (Bonda) & 320 & Tribe 2015 & $6 \mathrm{CT}$ \\
\hline Rhipidomys similis J. A. Allen, 1912 & Cau Hui VdC & $1000-2000$ & Tribe 2015 & CT \\
\hline Thomasomys baeops (Thomas, 1899) & $\begin{array}{l}\text { Ant Cau Hui } \\
\text { Nar }\end{array}$ & $2800-3200$ & Pacheco 2015 & EG \\
\hline Thomasomys paramorum Thomas, 1898 & Nar & 2800 & Pacheco 2015 & EG \\
\hline \multicolumn{5}{|l|}{ Rodentia, Echimyidae } \\
\hline Isothrix negrensis Thomas, 1920) & Vau & 100 & Emmons \& Patton 2015 & EG \\
\hline Isothrix orinoci (Thomas, 1899) & Vic & 100 & Emmons \& Patton 2015 & $\mathrm{CT}$ \\
\hline \multicolumn{5}{|l|}{ Rodentia, Erethizonthidae } \\
\hline \multicolumn{5}{|l|}{ Comentarios: } \\
\hline \multicolumn{5}{|c|}{ 1. Reemplaza a Lasiurus cinereus la cual fue restringida a Norte América pero no se ha definido la especie que se encuentra en Colombia. Baird et al. (2015) mencionaron que la } \\
\hline \multicolumn{5}{|c|}{$\begin{array}{l}\text { especie presente en Sudamérica es Aeorestes villosissimus (Geoffroy St.-Hilaire, 1806), sin embargo, la ausencia de muestras del norte de Sudamérica en dichos análisis deja en } \\
\text { duda el estatus taxonómico específico de las poblaciones colombianas antes incluidas en L. cinereus. Estas poblaciones representan un grupo morfológicamente homogéneo que }\end{array}$} \\
\hline \multirow{2}{*}{\multicolumn{5}{|c|}{ puede diferenciarse fácilmente de otras especies anteriormente incluidas en el género Lasiurus (Morales-Martínez \& Ramírez-Chaves 2015). }} \\
\hline & & & & \\
\hline \multicolumn{5}{|c|}{ 2. Previamente reconocida como subespecie de Saimiri sciureus. } \\
\hline \multicolumn{5}{|l|}{ 3. Reemplaza a Nectomys magdalenae en Solari et al. 2013.} \\
\hline \multicolumn{5}{|l|}{ 4. Reemplaza a Nephelomys sp. en Solari et al. 2013.} \\
\hline \multicolumn{5}{|c|}{ 5. Reemplaza a Oligoryzomys fulvescens en Solari et al. 2013.} \\
\hline omys nite & & & & \\
\hline
\end{tabular}

Aun cuando varios investigadores asumen que los mamíferos constituyen un grupo bien conocido (Temple \& Terry 2007), este no es el caso en las zonas tropicales, donde el entendimiento de los patrones de diversidad de este grupo parece un logro distante (Reeder et al. 2007, Ceballos \& Ehrlich 2009). Análisis previos muestran que el incremento en el número de especies de mamíferos no se restringe a aquellas pequeñas o crípticas (Ceballos \& Erich 2009, Rylands et al. 2012). Ceballos \& Ehrlich (2009) estimaron que el 40\% de 408 nuevas especies de mamíferos descritas a nivel mundial entre 1993 y 2008 no se encontraban incluidas formalmente dentro de otras especies (i.e., sinónimos o subespecies). Ante esta situación, se debe aumentar el esfuerzo de investigación en colecciones biológicas, mejorar y sistematizar los esfuerzos de campo, así como realizar análisis espaciales que permitan evidenciar las regiones que requieren un mayor esfuerzo de muestreo.

Desafortunadamente, y a pesar del papel de los especímenes biológicos como fuente de datos para diferentes estudios (Patterson 2002), algunas leyes nacionales, así como grupos que lideran estudios de impacto ambiental, parecen desincentivar la recolecta científica. Al ignorar la importancia del trabajo de campo intensivo y la revisión de especímenes de museo, se corre el riesgo de proveer información de mala calidad o a una escala inadecuada a los tomadores de decisiones. Además, se está perdiendo la oportunidad de obtener información genética y morfológica indispensable para entender aspectos básicos de taxonomía, conservación, variación intraespecífica y patrones de distribución de especies que permanecen ampliamente sin resolver. Es importante anotar que aunque los cambios registrados en este documento son soportados con diferentes tipos de evidencia, muchas de estas actualizaciones no han sido incluidas aún en plataformas como la IUCN (http://www.iucnredlist.org/), el GBIF (Global Biodiversity Information Facility; http://www.gbif.org/), o el Sistema de Información sobre Biodiversidad de Colombia (SIB). En este sentido, resaltamos la necesidad de enfocar nuevos esfuerzos en mantener un flujo más constante de esta información hacia bases de datos que puedan ser utilizadas por aquellos interesados en el manejo y el estudio de la biodiversidad.

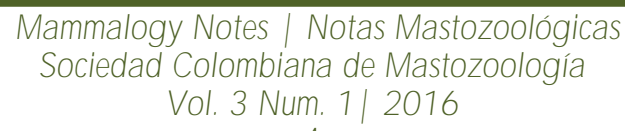


Tabla 2. Riqueza y endemismo de los órdenes de mamíferos presentes en Colombia para el año 2015.

\begin{tabular}{|c|c|c|c|c|}
\hline Orden* & Familias & Géneros & Especies & $\begin{array}{c}\text { Especies } \\
\text { Endémicas }\end{array}$ \\
\hline Didelphimorphia & 1 & $13 * *$ & 38 & 3 \\
\hline Paucituberculata & 1 & 1 & 2 & - \\
\hline Cingulata & 1 & 3 & 6 & - \\
\hline Pilosa & 4 & 5 & 7 & - \\
\hline Sirenia & 1 & 1 & 2 & - \\
\hline Soricomorpha & 1 & 1 & 7 & 5 \\
\hline Chiroptera & 9 & 72 & 205 & 7 \\
\hline Carnivora & 7 & $23 * * *$ & 34 & - \\
\hline Perissodactyla & 1 & 1 & 3 & - \\
\hline Artiodactyla & 2 & 5 & 12 & - \\
\hline Cetacea & 5 & 19 & 30 & - \\
\hline Primates & 5 & 15 & 38 & 10 \\
\hline Rodentia & 10 & 55 & 132 & 31 \\
\hline Lagomorpha & 1 & 1 & 2 & - \\
\hline Total & 49 & 215 & 518 & 56 \\
\hline \multicolumn{5}{|l|}{ Comentarios: } \\
\hline \multicolumn{5}{|c|}{ * Algunos autores incluyen a Artiodactyla y Cetacea en un único orden denominado Cetartiodactyla. } \\
\hline \multicolumn{5}{|c|}{$\begin{array}{l}\text { ** Autores como De la Sancha et al. (2012) y Voss et al. (2014) incluyen a Micoureus como un subgénero de Marmosa. Si se acepta } \\
\text { este cambio, el número de géneros de Didelphimorphia en el país sería } 12 .\end{array}$} \\
\hline
\end{tabular}

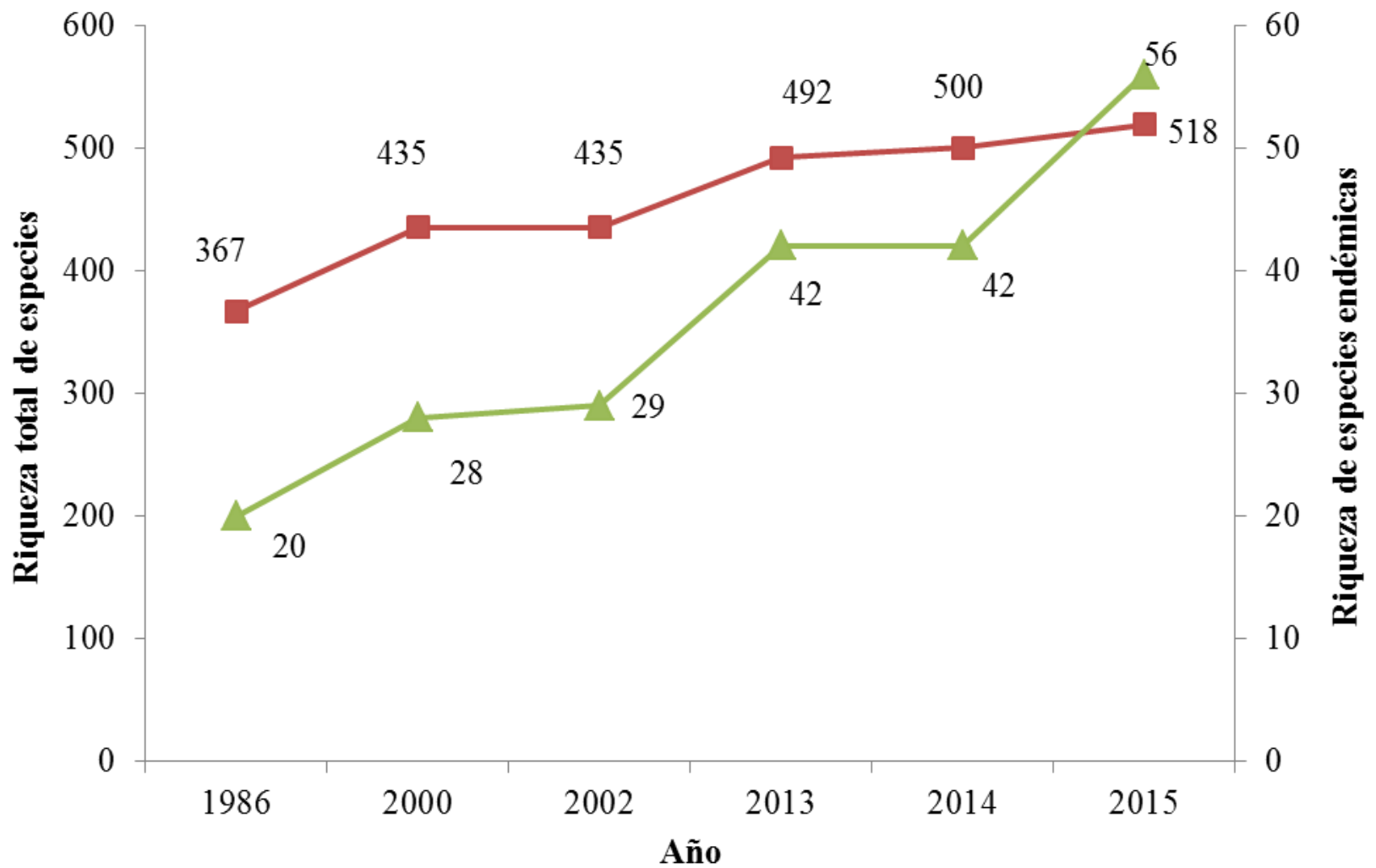

Figura 1. Incremento en riqueza total (cuadros) y riqueza de especies endémicas (triángulos) de mamíferos en Colombia a partir de las listas publicadas a nivel nacional desde 1986. 
Tabla 3. Países con mayor número de mamíferos a escala global. Los valores para Brasil y Perú

(*) se han incrementado en los últimos años pero no se ha cuantificado el incremento.

\begin{tabular}{|c|c|c|c|}
\hline País & Extensión $\left(\mathbf{K m}^{2}\right)$ & Mamíferos & Referencias \\
\hline Brasil & $8^{\prime} 511.996$ & $701 *$ & Paglia et al. 2012 \\
\hline Indonesia & 1'919.443 & 670 & $\begin{array}{l}\text { www.iucnredlist.org/initiatives/mammals/an } \\
\text { alysis }\end{array}$ \\
\hline China & 9'596.960 & 558 & Smith \& Xie 2013 \\
\hline México & 1'958.201 & 538 & $\begin{array}{c}\text { Ceballos \& Arroyo-Cabrales 2013, Ramírez- } \\
\text { Pulido } \text { et al. } 2014\end{array}$ \\
\hline Perú & $1^{\prime} 285.216$ & $529 *$ & Pacheco et al. 2009 y adiciones recientes \\
\hline Colombia & $1^{\prime} 141.748$ & 518 & Este trabajo \\
\hline
\end{tabular}

Referencias

ALBERICO, M. et al. 2000. Mamíferos (Synapsida: Theria) de Colombia. Biota Colombiana 1: 43-75.

BAIRD, A. M. et al. 2015. Molecular systematic revision of tree bats (Lasiurini): doubling the native mammals of the Hawaiian Islands. Journal of Mammalogy 96: 1255-1274.

BARNETT R. et al. 2005. Evolution of the extinct Sabretooths and the American Cheetah-like cat. Current Biology 15: R1R2.

BONVICINO, C. R. \& M. WEKSLER. 2015. Genus Nectomys Peters, 1861. Pp. 369-377 in Mammals of South America, Volume 2: Rodents (Patton, J.L., et al. eds.), The University of Chicago Press, USA.

BOUBLI, J. P. et al. 2012. Cebus phylogenetic relationships: A preliminary reassessment of the diversity of the untufted capuchin monkeys. American Journal of Primatology 74: 381-393.

BUCKNER, J. C., et al. 2015. Biogeography of the marmosets and tamarins (Callitrichidae). Molecular Phylogenetics and Evolution 82: 413-425.

BYRNE, H. et al. 2016. World titi monkeys (Callicebus): first appraisal of taxonomy based on molecular evidence. Frontiers in Zoology 13: 10

CALDERON W. \& V. PACHECO. 2012. First report of Artibeus bogotensis Andersen, 1906 (Chiroptera: Phyllostomidae) for Peru. Check List 8: 1333-1336.

CARLETON, M. D. \& G. G. MUSSER. 2015. Genus Oecomys Thomas, 1906. Pp. 393-417 in Mammals of South America, Volume 2: Rodents (Patton, J.L., et al. eds.), The University of Chicago Press, USA.

CEBALLOS, G. \& P. R. EHRLICH. 2009. Discoveries of new mammal species and their implications for conservation and ecosystem services. Proceedings of the National Academy of Sciences 106: 3841-3846.

CEBALLOS, G. \& J. ARROYO-CABRALES. 2013. Lista actualizada de los mamíferos de México 2012. Revista Mexicana de Mastozoología, nueva época 2: 27-80.

DE LA SANCHA, N. et al., 2012. Systematics of the subgenus of mouse opossums Marmosa (Micoureus) (Didelphimorphia, Didelphidae) with noteworthy records from Paraguay. Mammalian Biology 77: 229-236.

DE OLIVEIRA, J. A. \& P. R. GONÇALVES. 2015. Genus Oxymycterus Water house, 1837. Pp. 247-268 in Mammals of South America, Volume 2: Rodents (Patton, J.L., et al. eds.), The University of Chicago Press, USA.

DE VIVO, M. \& A. P. CARMIGNOTTO. 2015. Family Sciuridae G. Fischer, 1817. Pp. 1-48 in Mammals of South America, Volume 2: Rodents (Patton, J.L., et al. eds.), The University of Chicago Press, USA. 
D'ELÍA, G. et al ., 2015. Molecular systematics of South American marsh rats of the genus Holochilus (Muroidea, Cricetidae, Sigmodontinae). Journal of Mammalogy 96: 1081-1094.

DÍAZ, M. M. 2011. New records of bats from the northern region of the Peruvian Amazon. Zoological Research 32:168-178. DÍAZ-NIETO, J. F. et al. 2016. DNA sequencing reveals unexpected Recent diversityand an ancient dichotomy in the American marsupialgenus Marmosops (Didelphidae: Thylamyini). Zoological Journal of the Linnean Society 176: 914-940 EMMONS, L. H. \& J. L. PATTON. 2015. Genus Isothrix Wagner, 1845. Pp. 898-905 in Mammals of South America, Volume 2: Rodents (Patton, J.L., et al. eds.), The University of Chicago Press, USA.

GUTIÉRREZ, E. E., et al. 2015. The taxonomic status of Mazama bricenii and the significance of the Táchira depression for mammalian endemism in the Cordillera de Mérida, Venezuela. PLoS ONE 10: e0129113.

HAFNER, M. S. 2015 Family Geomyidae Bonaparte, 1845. Pp. 48-51 in Mammals of South America, Volume 2: Rodents (Patton, J.L., et al. eds.), The University of Chicago Press, USA.

HANSON et al. 2015. A new species of fish-eating rat, genus Neusticomys (Sigmodontinae), from Ecuador. Zoological Studies (2015) 54: 49.

HURTADO, N. \& V. PACHECO. 2014. Análisis filogenético del género Mimon Gray, 1847 (Mammalia, Chiroptera, Phyllostomidae) con la descripción de un nuevo género. Therya 5:751-791.

HURTADO, C. M. \& V. PACHECO. 2014. New mammalian records in the Parque Nacional Cerros de Amotape, northwestern Peru. Revista peruana de Biología 22:77-86.

JIMÉNEZ, C. F., et al. 2013. An introduction to the systematics of Akodon orophilus Osgood, 1913 (Rodentia: Cricetidae) with the description of a new species. Zootaxa 3669: 223-242.

LIM. B., et al. 2010. A new species of Peropteryx (Chiroptera: Emballonuridae) from western Amazonia with comments on phylogenetic relationships within the genus. American Museum Novitates 3686: 1-20.

LYNCH ALFARO, J. W., et al. 2015. Biogeography of squirrel monkeys (genus Saimiri): South-central Amazon origin and rapid pan-Amazonian diversification of a lowland primate. Molecular Phylogenetics and Evolution 82: 436-454.

MALDONADO, A. M. \& M. R. PECK. 2014. Research and in situ conservation of owl monkeys enhances environmental law enforcement at the Colombian-Peruvian border. American Journal of Primatology 76: 658-669.

MARSH, L. K. 2014. A taxonomic revision of the saki monkeys, Pithecia Desmarest, 1804. Neotropical Primates 21: 1-16. MEDINA, C. E., et al. 2014. A new species of Eumops (Chiroptera: Molossidae) from southwestern Peru. Zootaxa 3878: 1936.

MITTERMEIER, R. A., et al. (eds.) 2013. Handbook of the mammals of the world: 3. Primates. Lynx Ediciones, Barcelona, Spain.

MORALES-MARTÍNEZ, D. M. \& H. E. RAMÍREZ-CHAVES. 2015. The distribution of bats of genus Lasiurus (Vespertilionidae) in Colombia, with notes on taxonomy, morphology and ecology. Caldasia 37: 397-408.

MORATELLI, R. \& D. E. WILSON. 2014. A second record of Myotis diminutus (Chiroptera: Vespertilionidae): its bearing on the taxonomy of the species and discrimination from M. nigricans. Proceedings of the Biological Society of Washington 127: 533-542.

PACHECO, V. 2015. Genus Thomasomys Coues, 1884. Pp. 617-682 in Mammals of South America, Volume 2: Rodents (Patton, J.L., et al. eds.), The University of Chicago Press, USA.

PACHECO, V., et al. 2009. Diversidad y endemismo de los mamíferos del Perú. Revista peruana de Biología 16: 5-32.

PACHECO, V., et al. 2014. Una nueva especie de ratón orejón del género Phyllotis Waterhouse, 1837 (Rodentia: Cricetidae) del norte del Perú. Therya 5: 481-508.

PAGLIA, A. P., et al. 2012. Lista anotada dos mamíferos do Brasil / Annotated checklist of Brazilian Mammals. $2^{\mathrm{a}}$ Edição / 2nd Edition. Occasional papers in Conservation Biology (6). Conservation International. Arlington, VA. USA

PARDIÑAS, U. F. J., et al. 2015. Genus Necromys Ameghino, 1889. Pp. 232-247 in Mammals of South America, Volume 2: Rodents (Patton, J.L., et al. eds.), The University of Chicago Press, USA.

PATTERSON, B. D. 2002. On the continuing need for scientific collecting of mammals. Mastozoología Neotropical 9: 253262.

PATTON, J. L. \& R. N. LEITE. 2015. Genus Proechimys J. A. Allen, 1899. Pp. 950-989 in Mammals of South America, Volume 2: Rodents (Patton, J.L., et al. eds.), The University of Chicago Press, USA.

Mammalogy Notes | Notas Mastozoológicas

Sociedad Colombiana de Mastozoología

Vol. 3 Num. 1| 2016 
PATTON, J. L., et al. (eds.) 2015. Mammals of South America Volume 2. Rodents. The University of Chicago Press.

PERCEQUILlO, A. R. 2015. Genus Nephelomys Weksler, Percequillo, and Voss, 2006. Pp. 377-390 in Mammals of South America, Volume 2: Rodents (Patton, J.L., et al. eds.), The University of Chicago Press, USA.

QUIROGA-CARMONA, M. \& N. WOODMAN. 2015. A new species of Cryptotis (Mammalia, Eulipotyphla, Soricidae) from the Sierra de Perijá, Venezuelan-Colombian Andes. Journal of Mammalogy 96: 800-809.

RAMÍREZ-CHAVES, H. E., et al. 2016. Richness and distribution of porcupines (Erethizontidae: Coendou) from Colombia. Mammalia 80: 181-191.

RAMÍREZ-CHAVES, H. E. \& A. F. SUÁREZ-CASTRO, 2014. Adiciones y cambios a la lista de mamíferos de Colombia: 500especies registradas para el territorio nacional. Mammalogy Notes|Notas Mastozoológicas 1: 31-34.

RAMÍREZ-PULIDO, J., et al. 2014. List of recent land mammals of Mexico, 2014. Special publications, Museum of Texas Tech University 63: 1-69.

REEDER D.M., et al. 2007. Global Trends and Biases in New Mammal Species Discoveries. Occasional Papers Museum of Texas Tech University 269: 1-35

RENGIJO, E. M. \& V. PACHECO. 2015. Taxonomic revision of the Andean leaf-eared mouse, Phyllotis andium Thomas 1912 (Rodentia: Cricetidae), with the description of a new species. Zootaxa 4018: 349-380.

RYLANDS, A. B., et al. 2012. Neotropical primates: taxonomy and recently described species and subspecies. International Zoo Yearbook 46:11-24.

RYLANDS, A. B., et al. 2013. Family Cebidae (Squirrel Monkeys and Capuchins). Pp. 391-412 in Handbook of the Mammals of the World - Volume 3. Primates (Mittermeier, R., et al. eds.), Lynx Ediciones, Barcelona, Spain.

RODRÍGUEZ-POSADA, M. E. 2014. Primer registro del ratón de agua del Táchira, Neusticomys mussoi (Rodentia, Cricetidae) en Colombia. Mastozoología Neotropical 21: 367-372.

RUIZ-GARCÍA, M., et al. 2015. Phylogeography and spatial structure of the lowland tapir (Tapirus terrestris, Perissodactyla: Tapiridae) in South America. Mitochondrial DNA 1-9.

RUIZ-GARCÍA, M., et al. 2016. Mitogenomics of the mountain tapir (Tapirus pinchaque, Tapiridae, Perissodactyla, Mammalia) in Colombia and Ecuador: Phylogeography and insights into the origin and systematics of the South American tapirs. Mammalian Biology 81: 163-175.

SMITH, A. T. \& Y. XIE (eds.). 2013. Mammals of China . Princeton University Press, Princeton, New Jersey, USA.

SOLARI, S., et al. 2012. A new species of Monodelphis (Mammalia: Didelphimorphia: Didelphidae) from the montane forests of central Perú. Proceedings of the Biological Society of Washington, 125: 295-307.

SOLARI, S., et al. 2013. Riqueza, endemismo y conservación de los mamíferos de Colombia. Mastozoología Neotropical 20: 301-365.

SPOTORNO, A. E. \& J. A PATTON. 2015. Superfamily Chinchilloidea Bennett, 1833. Pp. 762-783 in Mammals of South America, Volume 2: Rodents (Patton, J.L., et al. eds.), The University of Chicago Press, USA.

TEMPLE, H .J. \& A. TERRY (comp.). 2007. The status and distribution of European mammals. Luxembourg: Office for Official Publications of the European Communities. viii +48.

TRIBE, C. J. 2015. Genus Rhipidomys Tschudi, 1845. Pp. 583-617 in Mammals of South America, Volume 2: Rodents (Patton, J.L., et al. eds.), The University of Chicago Press, USA.

VAN ROOSMALEN M. G. M., et al. 2002. A taxonomic review of the titi monkeys, genus Callicebus Thomas, 1903, with the description of two new species, Callicebus bernhardi and Callicebus stephennashi, from Brazilian Amazonia. Neotropical Primates 10 Supplement: 1-52.

VELAZCO, P. M. \& R. CADENILLAS. 2011. On the Identity of Lophostoma silvicolum occidentalis (Davis and Carter, 1978) (Chiroptera: Phyllostomidae). Zootaxa 2962: 1-20.

VELAZCO, P. M. \& B. D. PATTERSON. 2013. Diversification of the Yellow-Shouldered bats, genus Sturnira (Chiroptera, Phyllostomidae), in the New World Neotropics. Molecular Phylogenetics and Evolution 68: 683-698

VELAZCO, P. M., et al. 2014. Extraordinary local diversity of disk-winged bats (Thyropteridae: Thyroptera) in northeastern Peru, with the description of a new species and comments on roosting behavior. American Museum Novitates 3795: 1-28. VELAZCO, P. M., et al. 2010. Systematic of the Platyrrhinus helleri complex (Chiroptera: Phyllostomidae), with description of two new species. Zoological Journal of the Linnean Society 159: 785-812.

Mammalogy Notes | Notas Mastozoológicas

Sociedad Colombiana de Mastozoología

Vol. 3 Num. 1| 2016 
VELAZCO, S., et al. 2011. First occurrence of the rare emballonurid bat Cyttarops alecto (Thomas, 1913) in Peru - Only hard to find or truly rare. Mammalian Biology 76: 373-376.

VERMEER J. \& J. C. TELLO-ALVARADO. 2015. The distribution and taxonomy of titi monkeys (Callicebus) in Central and Southern Peru, with the description of a new species. Primate Conservation 29: 1-21.

VOSS, R. S. 2015. Genus Zygodontomys J. A. Allen, 1897. Pp. 460-465 in Mammals of South America, Volume 2: Rodents (Patton, J.L., et al. eds.), The University of Chicago Press, USA.

VOSS, R. S., et al. 2014. Phylogenetic relationships of mouse opossums (Didelphidae, Marmosa) with a revised subgeneric classification and notes on sympatric diversity. American Museum Novitates 3817: 1-27

WEKSLER, M. \& C. R. BONVICINO. 2015. Genus Oligoryzomys Bangs, 1900. Pp. 417-437 in Mammals of South America, Volume 2: Rodents (Patton, J.L., et al. eds.), The University of Chicago Press, USA. 


\section{INFORMACIÓN SUPLEMENTARIA}

Ramírez-Chaves et al.

Tabla S1. Cambios a la lista de mamíferos de Colombia (2014-marzo 2016). *Especies endémicas. T: cambios taxonómicos con respecto a la lista de Solari et al. (2013) que no afectaron el conteo de especies. + Adiciones con respecto a la lista de Solari et al. (2013) hasta marzo 2016. CT: Adición por cambios taxonómicos. EG: Adición por extensión geográfica. NE: Adición de especies recientemente descritas.

\begin{tabular}{|c|c|}
\hline Taxón & Comentarios \\
\hline \multicolumn{2}{|l|}{ DIDELPHIMORPHIA } \\
\hline Caluromys derbianus (Waterhouse, 1841) & \\
\hline Caluromys lanatus (Olfers, 1818) & \\
\hline Caluromysiops irrupta Sanborn, 1951 & \\
\hline Glironia venusta Thomas, 1912 & \\
\hline Chironectes minimus (Zimmermann, 1780) & \\
\hline Didelphis marsupialis Linnaeus, 1758 & \\
\hline Didelphis pernigra J.A. Allen, 1900 & \\
\hline Gracilinanus dryas (Thomas, 1898) & \\
\hline Gracilinanus emiliae (Thomas, 1909) & \\
\hline Gracilinanus marica (Thomas, 1898) & \\
\hline Gracilinanus sp.* & \\
\hline Lutreolina crassicaudata (Desmarest, 1804) & \\
\hline Marmosa isthmica Goldman, 1912 & \\
\hline Marmosa lepida (Thomas, 1888) & \\
\hline Marmosa robinsoni Bangs, 1898 & \\
\hline Marmosa rubra Tate, 1931 & \\
\hline Marmosa waterhousei (Tomes, 1860) & \\
\hline Marmosa xerophila Handley \& Gordon, 1979 & \\
\hline Marmosa zeledoni Goldman, 1911 & \\
\hline Marmosops bishopi (Pine, 1981) & \\
\hline Marmosops caucae (Thomas, 1900)* & \\
\hline Marmosops fuscatus (Thomas, 1896) & \\
\hline Marmosops handleyi (Pine, 1981)* & \\
\hline Marmosops noctivagus (Tschudi, 1845) & \\
\hline Marmosops parvidens (Tate, 1931) & \\
\hline Metachirus nudicaudatus (É. Geoffroy Sant-Hilaire, 1803) & \\
\hline Micoureus alstoni (J.A. Allen, 1900) & \\
\hline Micoureus demerarae (Thomas, 1905) & \\
\hline Micoureus phaeus (Thomas, 1899) & \\
\hline Micoureus regina (Thomas, 1898) & \\
\hline Monodelphis adusta (Thomas, 1897) & \\
\hline Monodelphis brevicaudata (Erxleben, 1777) & \\
\hline Monodelphis melanops (Goldman, 1912) & \\
\hline Monodelphis palliolata (Osgood, 1914) & \\
\hline Monodelphis sp. & \\
\hline Philander andersoni (Osgood, 1913) & \\
\hline Philander mondolfii Lew, Pérez-Hernández \& Ventura, 2006 & \\
\hline Philander opossum (Linnaeus, 1758) & \\
\hline
\end{tabular}

Philander mondolfii Lew, Pérez-Hern

Caenolestes convelatus Anthony, 1924

PAUCITUBERCULATA

Caenolestes fuliginosus (Tomes, 1863)

Cabassous centralis (Miller, 1899)

Cabassous unicinctus (Linnaeus, 1758)

Dasypus kappleri Krauss, 1862

CINGULATA 


\section{Apéndices | Appendices}

Dasypus novemcinctus Linnaeus, 1758

Dasypus sabanicola Mondolfi, 1968

Priodontes maximus (Kerr, 1792)

Bradypus variegatus Schinz, 1825

PILOSA

Choloepus didactylus (Linnaeus, 1758)

Choloepus hoffmanni Peters, 1858

Cyclopes didactylus (Linnaeus, 1758)

Tamandua mexicana (Saussure, 1860)

Tamandua tetradactyla (Linnaeus, 1758)

Myrmecophaga tridactyla Linnaeus, 1758

Trichechus inunguis (Natterer, 1883)

Trichechus manatus Linnaeus, 1758

Cryptotis brachyonyx Woodman, 2003*

SORICOMORPHA

Cryptotis colombianus Woodman \& Timm, 1993*

Cryptotis medellinius Thomas, 1921*

Cryptotis perijensis Quiroga Carmona \& Woodman, 2015

Cryptotis squamipes (J.A. Allen, 1912)*

Cryptotis tamensis Woodman, 2002

Cryptotis thomasi (Merriam, 1897)*

Balantiopteryx infusca (Thomas, 1897)

Centronycteris centralis Thomas, 1912

Cormura brevirostris (Wagner, 1843)

Cyttarops alecto Thomas, 1913

Diclidurus albus Wied-Neuwied, 1820

Diclidurus ingens Hernández-Camacho, 1955

Diclidurus scutatus Peters, 1869

Peropteryx kappleri Peters, 1867

Peropteryx leucoptera Peters, 1867

Peropteryx macrotis (Wagner, 1843)

Peropteryx pallidoptera Lim, Engstrom, Reid, Simmons, Voss \& Fleck, 2010

Rhynchonycteris naso (Wied-Neuwied, 1820)

Saccopteryx antioquensis Muñoz \& Cuartas-Calle, 2001*

Saccopteryx bilineata (Temminck, 1838)

Saccopteryx canescens Thomas, 1901

Saccopteryx leptura (Schreber, 1774)

Noctilio albiventris Desmarest, 1818

Noctilio leporinus (Linnaeus, 1758)

Mormoops megalophylla (Peters, 1864)

Pteronotus davyi Gray, 1838

Pteronotus gymnonotus (Wagner, 1843)

Pteronotus parnellii (Gray, 1843)

Pteronotus personatus (Wagner, 1843)

Carollia brevicauda (Schinz, 1821)

Carollia castanea $\mathrm{H}$. Allen, 1890

Carollia monohernandezi Muñoz, Cuartas-Calle \& González, 2004*

Carollia perspicillata (Linnaeus, 1758)

Carollia sp.

Rhinophylla alethina Handley, 1966

Rhinophylla fischerae Carter, 1966

Rhinophylla pumilio Peters, 1865

Desmodus rotundus (É. Geoffroy Saint Hilaire, 1810)

Diaemus youngii (Jentink, 1893)

Diphylla ecaudata Spix, 1823

Anoura aequatoris (Lönnberg, 1921)

Anoura cadenai Mantilla-Meluk \& Baker, 2006*

Anoura carishina Mantilla-Meluk \& Baker, 2010*

Mammalogy Notes | Notas Mastozoológicas

Sociedad Colombiana de Mastozoología

Vol. 3 Num. 1| 2016 
Anoura caudifer (É. Geoffroy Saint-Hilaire, 1818)

Anoura cultrata Handley, 1960

Anoura fistulata Muchhala, Mena \& Albuja, 2005

Anoura geoffroyi Gray, 1838

Anoura latidens Handley, 1984

Anoura luismanueli Molinari, 1994

Anoura peruana (Tschudi, 1844)

Choeroniscus godmani (Thomas, 1903)

Choeroniscus minor (Peters, 1868)

Choeroniscus periosus Handley, 1966

Glossophaga commissarisi Gardner, 1962

Glossophaga longirostris Miller, 1898

Glossophaga soricina (Pallas, 1766)

Leptonycteris curasoae Miller, 1900

Lichonycteris degener Miller, 1931

Lichonycteris obscura Thomas, 1895

Lionycteris spurrelli Thomas, 1913

Hsunycteris cadenai (Woodman \& Timm, 2006)

Hsunycteris pattoni Woodman \& Timm, 2006

Hsunycteris thomasi (J.A Allen, 1904)

Lonchophylla chocoana Dávalos, 2004

Lonchophylla concava Goldman, 1914

Lonchophylla fornicata Woodman, 2007

Lonchophylla handleyi Hill, 1980

Lonchophylla orienticollina Dávalos \& Corthals, 2008

Lonchophylla robusta Miller, 1912

Chrotopterus auritus (Peters, 1865)

Gardnerycteris crenulatum (É. Geoffroy Saint Hilaire, 1803)

Glyphonycteris daviesi (Hill 1964)

Glyphonycteris sylvestris Thomas, 1896

Lampronycteris brachyotis (Dobson, 1879)

Lonchorhina aurita Tomes, 1863

Lonchorhina marinkellei Hernández-Camacho \& Cadena, 1978*

Lonchorhina orinocensis Linares \& Ojasti, 1971

Lophostoma brasiliense Peters, 1867

Lophostoma carrikeri (J.A. Allen, 1910)

Lophostoma occidentalis (Davis \& Carter 1978)

Lophostoma silvicolum d'Orbigny, 1836

Macrophyllum macrophyllum (Schinz, 1821)

Micronycteris hirsuta (Peters, 1869)

Micronycteris megalotis (Gray, 1842)

Micronycteris microtis Miller, 1898

Micronycteris minuta (Gervais, 1856)

Micronycteris schmidtorum Sanborn, 1935

Mimon bennettii (Gray, 1838)

Mimon cozumelae Goldman, 1914

Phylloderma stenops Peters, 1865

Phyllostomus discolor (Wagner, 1843)

Phyllostomus elongatus (É. Geoffroy Saint Hilaire, 1810)

Phyllostomus hastatus (Pallas, 1767)

Phyllostomus latifolius (Thomas, 1901)

Tonatia saurophila Koopman \& Williams, 1951

Trachops cirrhosus (Spix, 1823)

Trinycteris nicefori (Sanborn, 1949)

Vampyrum spectrum (Linnaeus, 1758)

Ametrida centurio Gray, 1847

Artibeus aequatorialis K. Andersen, 1906

Artibeus amplus Handley, 1987

Artibeus concolor Peters, 1865

Artibeus jamaicensis Leach, 1821

Mammalogy Notes | Notas Mastozo ológicas

Sociedad Colombiana de Mastozoología

Vol. 3 N um. 1| 2016 
Artibeus lituratus (Olfers, 1818)

Artibeus obscurus (Schinz, 1821)

Artibeus planirostris (Spix, 1823)

Centurio senex Gray, 1842

Chiroderma salvini Dobson, 1878

Chiroderma trinitatum Goodwin, 1958

Chiroderma villosum Peters, 1860

Dermanura anderseni (Osgood, 1916)

Dermanura bogotensis (K. Andersen, 1906)

Dermanura glauca (Thomas, 1893)

Dermanura gnoma (Handley, 1987)

Dermanura phaeotis Miller, 1902

Dermanura rava Miller, 1902

Dermanura rosenbergi Thomas, 1897

Enchisthenes hartii (Thomas, 1892)

Mesophylla macconnelli Thomas, 1901

Platyrrhinus albericoi Velazco, 2005

Platyrrhinus angustirostris Velazco, Gardner \& Patterson, 2010

Platyrrhinus brachycephalus (Rouk \& Carter, 1972)

Platyrrhinus chocoensis Alberico \& Velasco-A., 1991

Platyrrhinus dorsalis (Thomas, 1900)

Platyrrhinus helleri (Peters, 1866)

Platyrrhinus incarum (Thomas, 1912)

Platyrrhinus infuscus (Peters, 1880)

Platyrrhinus ismaeli Velazco, 2005

Platyrrhinus matapalensis Velazco, 2005

Platyrrhinus nigellus (Gardner \& Carter, 1972)

Platyrrhinus nitelinea Velazco \& Gardner, 2009

Platyrrhinus umbratus (Lyon, 1902)

Platyrrhinus vittatus (Peters, 1859)

Sphaeronycteris toxophyllum Peters, 1882

Sturnira aratathomasi Peterson \& Tamsitt, 1968

Sturnira bidens (Thomas, 1915)

Sturnira bogotensis Shamel, 1927

Sturnira erythromos (Tschudi, 1844)

Sturnira koopmanhilli McCarthy, Albuja \& Alberico, 2006

Sturnira ludovici Anthony, 1924

Sturnira luisi Davis, 1980

Sturnira magna de la Torre, 1966

Sturnira mistratensis Contreras-Vega \& Cadena, 2000*

Sturnira cf. lilium (É. Geoffroy Saint Hilaire, 1806)

Sturnira tildae de la Torre, 1959

Uroderma bakeri Mantilla-Meluk 2014

Uroderma bilobatum Peters, 1866

Uroderma convexum Lyon 1902

Uroderma magnirostrum Davis, 1968

Vampyressa melissa Thomas, 1926

Vampyressa sinchi Tavares, Gardner, Ramírez-Chaves \& Velazco 2014*

Vampyressa thyone Thomas, 1909

Vampyriscus bidens (Dobson, 1878)

Vampyriscus brocki (Peterson, 1968)

Vampyriscus nymphaea (Thomas, 1909)

Vampyrodes caraccioli (Thomas, 1889)

Vampyrodes major Allen, 1908

Furipterus horrens (F. Cuvier, 1828)

Chilonatalus micropus (Dobson, 1880)

Natalus mexicanus Miller, 1902

Natalus tumidirostris Miller, 1900

Thyroptera discifera (Lichtenstein \& Peters, 1854)

Thyroptera lavali Pine, 1993

$+\mathrm{NE}$

$+\mathrm{CT}$

$+\mathrm{NE}$ 


\section{Apéndices | Appendices}

Thyroptera tricolor Spix, 1823

Eptesicus andinus J.A. Allen, 1914

Eptesicus brasiliensis (Desmarest, 1819)

Eptesicus chiriquinus Thomas, 1920

Eptesicus furinalis (D'Orbigny \& Gervais, 1847)

Eptesicus fuscus (Palisot de Beauvois, 1796)

Histiotus humboldti Handley, 1996

Histiotus montanus (Philippi \& Landbeck, 1861)

Aeorestes sp.

Dasypterus ega (Gervais, 1856)

$\mathrm{T}$ $\mathrm{T}$

Lasiurus blossevillii (Lesson, 1826)

Myotis albescens (É. Geoffroy Saint Hilaire, 1806)

Myotis caucensis J.A. Allen 1914

Myotis diminutus Moratelli \& Wilson, 2011

Myotis keaysi J.A. Allen, 1914

Myotis nesopolus Miller, 1900

Myotis nigricans (Schinz, 1821)

Myotis oxyotus (Peters, 1866)

Myotis pilosatibialis LaVal 1973

Myotis riparius Handley, 1960

Myotis simus Thomas, 1901

Rhogeessa io Thomas, 1903

Rhogeessa minutilla Miller, 1897

Cynomops abrasus (Temminck, 1826)

Cynomops greenhalli Goodwin, 1958

Cynomops paranus (Thomas, 1901)

Cynomops planirostris (Peters, 1866)

Eumops auripendulus (G. Shaw, 1800)

Eumops dabbenei Thomas, 1914

Eumops delticus Thomas, 1923

Eumops glaucinus (J.A. Wagner, 1843)

Eumops nanus (Miller, 1900)

Eumops perotis (Schinz, 1821)

Eumops trumbulli (Thomas, 1901)

Molossops neglectus Williams \& Genoways, 1980

Molossops temmincki (Burmeister, 1854)

Neoplatymops mattogrossensis (C.O.C. Vieira, 1942)

Molossus bondae J.A. Allen, 1904

Molossus coibensis J.A. Allen, 1904

Molossus molossus (Pallas, 1766)

Molossus pretiosus Miller, 1902

Molossus rufus É. Geoffroy Saint Hilaire, 1805

Molossus sinaloae J.A. Allen, 1906

Nyctinomops aurispinosus (Peale, 1848)

Nyctinomops laticaudatus (É. Geoffroy Saint Hilaire, 1805)

Nyctinomops macrotis (Gray, 1839)

Promops centralis Thomas, 1915

Tadarida brasiliensis (I. Geoffroy, 1824)

Leopardus pajeros (Desmarest, 1816)

Leopardus pardalis (Linnaeus, 1758)

Leopardus tigrinus (Schreber, 1775)

Leopardus wiedii (Schinz, 1821)

Panthera onca (Linnaeus, 1758)

Puma concolor (Linnaeus, 1771)

Puma yagouaroundi (É. Geoffroy Sant-Hilaire, 1803)

Atelocynus microtis (Sclater, 1883)

Cerdocyon thous (Linnaeus, 1766)

Lycalopex culpaeus (Molina, 1782)

Speothos venaticus (Lund, 1842)
$+\mathrm{CT}$

$+\mathrm{EG}$

$+\mathrm{CT}$

Mamma logy Notes | Notas Mastozoológicas

Sociedad Colombiana de Mastozoología

Vol. 3 N um. 1| 2016 


\section{Apéndices | Appendices}

Urocyon cinereoargenteus (Schreber, 1775)

Conepatus semistriatus (Boddaert, 1785)

Eira barbara (Linnaeus, 1758)

Galictis vittata (Schreber, 1776)

Lontra longicaudis (Olfers, 1818)

Mustela felipei Izor \& de la Torre, 1978

Mustela frenata Lichtenstein, 1831

Pteronura brasiliensis (Gmelin, 1788)

Arctocephalus australis (Zimmermann, 1783)

Arctocephalus galapagoensis Heller 1904

Arctochephalus philippi (Peters 1866)

Otaria flavescens (Shaw, 1800)

Zalophus wollebaeki Siverstsen, 1953

Bassaricyon alleni Thomas, 1880

Bassaricyon medius Thomas 1909

Bassaricyon neblina Helgen, Pinto, Kays, Helgen, Tsuchiya, Quinn, Wilson \& Maldonado 2013

Nasua narica (Linnaeus, 1766)

Nasua nasua (Linnaeus, 1766)

Nasuella olivacea (Gray, 1865)

Potos flavus (Schreber, 1774)

Procyon cancrivorus (G. Cuvier, 1798)

Procyon lotor (Linnaeus, 1758)

Tremarctos ornatus (F.G. Cuvier, 1825)

Tapirus bairdii (Gill, 1865)

Tapirus pinchaque (Roulin, 1829)

Tapirus terrestris (Linnaeus, 1758)

Pecari tajacu (Linnaeus, 1758)

Tayassu pecari (Link, 1795)

Mazama murelia J. A. Allen, 1915

Mazama rufina (Pucheran, 1851)

Mazama sanctaemartae J. A. Allen, 1915

Mazama temama (Kerr, 1792)

Mazama zamora J. A. Allen, 1915

Mazama zetta Thomas, 1913

Odocoileus cariacou (Boddaert, 1784)

Odocoileus goudotii (Gay \& Gervais, 1846)

Odocoileus ustus Trouessart, 1910

Pudu mephistophiles (de Winton, 1896)

Balaenoptera acutorostrata Lacépède, 1804

PERISSODACTYLA

Balaenoptera borealis Lesson, 1828

Balaenoptera edeni Anderson, 1879

Balaenoptera musculus (Linnaeus, 1758)

Balaenoptera physalus (Linnaeus, 1758)

Megaptera novaeangliae (Borowski, 1781)

Delphinus capensis Gray, 1828

Delphinus delphis Linnaeus, 1758

Feresa attenuata Gray, 1874

Globicephala macrorhynchus Gray, 1846

Grampus griseus (G. Cuvier, 1812)

Lagenodelphis hosei Fraser, 1956

Orcinus orca (Linnaeus, 1758)

Peponocephala electra (Gray, 1846)

Pseudorca crassidens (Owen, 1846)

Sotalia fluviatilis (Gervais \& Deville, 1853)

Sotalia guianensis (Van Bénéden, 1864)

Stenella attenuata (Gray, 1846)

Stenella coeruleoalba (Meyen, 1833)

Mammalogy Notes | Notas Mastozoológicas

Sociedad Colombiana de Mastozoología

Vol. 3 N um. 1| 2016 
Stenella frontalis (G. Cuvier, 1829)

Stenella longirostris (Gray, 1828)

Steno bredanensis (G. Cuvier, 1828)

Tursiops truncatus (Montagu, 1821)

Inia geoffrensis (Blainville, 1817)

Kogia breviceps (Blainville, 1838)

Kogia sima (Owen, 1866)

Physeter macrocephalus Linnaeus, 1758

Mesoplodon densirostris (Blainville, 1817)

Mesoplodon europaeus (Gervais, 1855)

Ziphius cavirostris G. Cuvier, 1823

Aotus brumbacki Hershkovitz, 1983*

\section{PRIMATES}

Aotus griseimembra Elliot, 1912*

Aotus jorgehernandezi Defler \& Bueno, 2007*

Aotus lemurinus (I. Geoffroy, 1843)

Aotus vociferans (Spix, 1823)

Aotus zonalis Goldman, 1914

Alouatta palliata (Gray, 1849)

Alouatta seniculus Linnaeus, 1766

Ateles belzebuth É. Geoffroy Saint Hilaire, 1806

Ateles geoffroyi Kuhl, 1820

Ateles hybridus I. Geoffroy, 1829

A. hybridus brunneus Gray, 1872*

A. hybridus hybridus I. Geoffroy, 1829

Lagothrix lagothricha Humboldt, 1812

Callimico goeldii (Thomas, 1904)

Cebuella pygmaea (Spix, 1823)

Leontocebus fuscus (Lesson, 1840)

Leontocebus nigricollis (Spix, 1823)

L. nigricollis hernandezi (Hershkovitz, 1982*)

L. nigricollis nigricollis (Spix, 1823)

L. nigricollis graellsi (Jiménez de la Espada, 1870)

Saguinus geoffroyi (Pucheran, 1845)

Saguinus inustus (Schwartz, 1951)

Saguinus leucopus (Günther, 1877)*

Saguinus oedipus (Linnaeus, 1758)*

Cebus albifrons (Humboldt, 1812)

C. albifrons cuscinus Thomas, 1901

Cebus leucocephalus Gray, 1865

Cebus malitiosus Elliot, 1909 *

Cebus versicolor Pucheran, 1845

Cebus capucinus (Linnaeus, 1758)

Saimiri cassiquiarensis Lesson, 1840

Saimiri macrodon Elliot, 1907

Sapajus apella (Linnaeus, 1758)

Cheracebus lucifer Thomas, 1914

Cheracebus lugens (Humboldt, 1811)

Cheracebus medemi Hershkovitz, 1963*

Cheracebus torquatus (Hoffmannsegg, 1807)

Plecturocebus caquetensis (Defler, Bueno \& García, 2010)*

Plecturocebus discolor (I. Geoffroy \& Deville, 1848)

Plecturocebus ornatus (Gray, 1866)*

Cacajao melanocephalus Humboldt, 1812

Pithecia hirsuta Spix 1823

Pithecia milleri J.A. Allen, 1914

Guerlinguetus aestuans (Linnaeus, 1766)

Hadrociurus igniventris (Wagner, 1842)

Hadrosciurus spadiceus (Olfers, 1818)

$+\mathrm{CT}$

$+\mathrm{CT}$

$+\mathrm{CT}$

$\mathrm{T}$

$+\mathrm{CT}$

$+\mathrm{CT}$

$\mathrm{T}$

+ CT

$\mathrm{T}$

$\mathrm{T}$

$\mathrm{T}$

$\mathrm{T}$

$\mathrm{T}$

$+\mathrm{CT}$

RODENTIA

CT EG

$\mathrm{T}$

$\mathrm{T}$

Mammalogy Notes | Notas Mastozoológicas

Sociedad Colombiana de Mastozoología

Vol. 3 N um. 1| 2016 


\section{Apéndices | Appendices}

Microsciurus flaviventer (Gray, 1867)

Microsciurus isthmius (E. W. Nelson, 1899)

$+\mathrm{CT}$

Microsciurus mimulus (Thomas, 1898)

Microsciurus otinus (Thomas, 1901)*

Microsciurus santanderensis (Hernández-Camacho, 1957)*

Microsciurus similis (E. W. Nelson, 1899)

Notosciurus granatensis (Humboldt, 1811)

Notosciurus pucheranii (Fitzinger, 1867)

Sciurillus pusillus (É. Geoffroy Saint-Hilaire, 1803)

Orthogeomys dariensis (Goldman, 1912)

Heteromys anomalus (Thompson, 1815)

Heteromys australis Thomas, 1901

Heteromys desmarestianus Gray, 1868

Isthmomys pirrensis (Goldman, 1912)

Reithrodontomys mexicanus (Saussure, 1860)

Aepeomys lugens (Thomas, 1896)

Akodon affinis (J.A. Allen, 1912)*

Calomys hummelincki (Husson, 1960)

Chibchanomys trichotis (Thomas, 1897)

Chilomys fumeus Osgood, 1912

Chilomys instans (Thomas, 1895)

Euryoryzomys macconnelli (Thomas, 1910)

Handleyomys alfaroi (J.A. Allen, 1891)

Handleyomys fuscatus (J.A. Allen, 1912)*

Handleyomys intectus (Thomas, 1921)*

Holochilus sciureus Wagner, 1842

Hylaeamys perenensis (J.A. Allen, 1901)

Hylaeamys yunganus (Thomas, 1902)

Ichthyomys hydrobates (Winge, 1891)

Melanomys caliginosus (Tomes, 1860)

Melanomys columbianus (Allen, 1899)

Microryzomys altissimus (Osgood, 1933)

Microryzomys minutus (Tomes, 1860)

Neacomys spinosus (Thomas, 1882)

Neacomys tenuipes Thomas, 1900

Necromys urichi (J.A. Allen \& Chapman, 1897)

Necromys punctulatus (Thomas, 1894)

Nectomys grandis Thomas, 1897*

Nectomys rattus (Pelzen, 1883)

Neomicroxus bogotensis (Thomas, 1895)

Nephelomys childi (Thomas, 1895)*

Nephelomys maculiventer (J.A. Allen, 1891)*

Nephelomys meridensis (Thomas, 1894)

Nephelomys pectoralis (J.A. Allen, 1912)*

Neusticomys monticolus Anthony 1921

Neusticomys mussoi Ochoa \& Soriano, 1991

Neusticomys vossi Hanson, D’Elía, Ayers, Cox, Burneo \& LeJ r., 2015

Oecomys bicolor (Tomes, 1860)

Oecomys concolor (Wagner, 1845)

Oecomys flavicans (Thomas, 1894)

Oecomys roberti (Thomas, 1904)

Oecomys speciosus (J.A. Allen \& Chapman, 1893)

Oecomys superans Thomas, 1911

Oecomys trinitatis (J.A. Allen \& Chapman, 1893)

Oligoryzomys delicatus (J. A. Allen \& Chapman, 1897)

Oligoryzomys destructor (Tschudi, 1844)

Oligoryzomys griseolus (Osgood, 1912)

Oryzomys couesi (Alston, 1877)

Oryzomys gorgasi Hershkovitz, 1971

Rhipidomys caucensis J.A. Allen, 1913* 


\section{Apéndices | Appendices}

Rhipidomys couesi (J.A. Allen \& Chapman, 1893)

Rhipidomys fulviventer Thomas, 1896*

Rhipidomys latimanus (Tomes, 1860)

Rhipidomys leucodactylus (Tschudi, 1845)

Rhipidomys similis J. A. Allen, 1912*

Rhipidomys venezuelae Thomas, 1896

Rhipidomys sp. nov*

Scolomys ucayalensis Pacheco, 1991

Sigmodon alstoni (Thomas, 1881)

Sigmodon hirsutus (Burmeister, 1854)

Sigmodontomys alfari J.A. Allen, 1897

Thomasomys aureus (Tomes, 1860)

Thomasomys baeops (Thomas, 1899)

Thomasomys bombycinus Anthony, 1925*

Thomasomys cinereiventer J.A. Allen, 1912*

Thomasomys cinnameus Anthony, 1924

Thomasomys contradictus Anthony, 1925*

Thomasomys dispar Anthony 1925*

Thomasomys hylophilus Osgood, 1912

Thomasomys laniger (Thomas, 1895)*

Thomasomys monochromos Bangs, 1900*

Thomasomys nicefori Thomas, 1921*

Thomasomys niveipes (Thomas, 1896)*

Thomasomys paramorum Thomas, 1898

$+\mathrm{EG}$

$+\mathrm{CT}$

$+\mathrm{NE}$

Thomasomys popayanus J. A. Allen, 1912*

Thomasomys princeps (Thomas, 1895)*

Transandinomys bolivaris (J.A. Allen, 1901)

Transandinomys talamancae (J.A. Allen, 1891)

Zygodontomys brevicauda (J.A. Allen \& Chapman, 1893)

Zygodontomys brunneus Thomas, 1898*

Tylomys mirae Thomas, 1899

Coendou ichillus Voss \& da Silva, 2001

Coendou prehensilis (Linnaeus, 1758)

Coendou pruinosus Thomas, 1905

Coendou quichua Thomas, 1899

Coendou rufescens (Gray, 1865)

Coendou vestitus Thomas, 1899*

Cavia aperea Erxleben, 1777

Cavia porcellus (Linnaeus, 1758)

Hydrochoerus hydrochaeris (Linnaeus, 1766)

Hydrochoerus isthmius Goldman, 1912

Cuniculus paca (Linnaeus, 1766)

Cuniculus taczanowskii (Stolzmann, 1865)

Dasyprocta fuliginosa Wagler, 1832

Dasyprocta punctata Gray, 1842

Myoprocta cf. acouchi Erxleben 1777

Myoprocta pratti Pocock, 1913

Dinomys branickii Peters, 1873

Dactylomys dactylinus (Desmarest, 1817)

Olallamys albicaudus (Günther, 1879)*

Diplomys caniceps (Günther, 1877)

Diplomys labilis (Bangs, 1901)

Isothrix bistriata Wagner, 1845

Isothrix negrensis Thomas, 1920

Isothrix orinoci (Thomas, 1899)

Makalata didelphoides (Desmarest, 1817)

Pattonomys semivillosus (I. Geoffroy, 1838)*

Santamartamys rufodorsalis (J.A. Allen, 1899)*

Hoplomys gymnurus (Thomas, 1897)

Mesomys hispidus (Desmarest, 1817)

Mammalogy Notes | Notas Mastozoológicas

Sociedad Colombiana de Mastozoología

Vol. 3 N um. 1| 2016

+ EG

$+\mathrm{CT}$ 
Proechimys brevicauda (Günther, 1877)

Proechimys canicollis (J.A. Allen, 1899)

Proechimys chrysaeolus (Thomas, 1898)*

Proechimys mincae (J.A. Allen, 1899)*

Proechimys oconnelli J.A. Allen, 1913*

Proechimys poliopus Osgood, 1914

Proechimys quadruplicatus Hershkovitz, 1948

Proechimys semispinosus (Tomes, 1860)

Proechimys simonsi Thomas, 1900

Sylvilagus brasiliensis (Linnaeus, 1758)

LAGOMORPHA

Sylvilagus floridanus (J.A. Allen, 1890) 